\title{
Acute in Vitro effects of ABS (Ankaferd Hemostat) on the Lymphoid Neoplastic Cells (B-CLL and RAJI Tumor Cell Lines)
}

\author{
Ibrahim AKALIN ${ }^{1,2}$, Fatma V. OKUR ${ }^{2,3}$, Ibrahim C. HAZNEDAROGLU ${ }^{3}$, Nilgun SAYINALP ${ }^{3}$, \\ Salih AKSU ${ }^{3}$, Yahya BUYUKASIK ${ }^{3}$, Hakan GOKER ${ }^{3}$ \\ ${ }^{1}$ Istanbul Medeniyet University Faculty of Medicine, Department of Medical Genetics, Istanbul, TURKEY \\ ${ }^{2}$ Baylor College of Medicine, Center for Cell and Gene Therapy, Houston, Texas, USA \\ ${ }^{3}$ Hacettepe University Faculty of Medicine, Department of Hematology, Ankara, TURKEY
}

\begin{abstract}
ABS (Ankaferd Hemostat) has emerged as a novel haemostatic agent of plant origin. Its ability to interact with entire proteins including cell surface receptors and/or blood proteins plus tissue proteins revealed novel functions of ABS to biologic systems especially tumor associated transcription factors. Thus, in our study, we aimed to investigate the effects of ABS on lymphoid neoplastic cells in vitro. We showed that Ankaferd treated B-CLL cells (at doses $0.5,1$ and $2 \mu \mathrm{g} / \mathrm{mL}$ ) ceased to inflate and more than $50 \%$ of tumor cells were died compared to 0.1 and $0.25 \mu \mathrm{g} / \mathrm{mL}$ doses. Additionally, transformation of B-CLL cells to the blastic aggressive lymphoid forms was prevented by addition of Ankaferd to culture medium. The results have given the clues of anti-neoplastic effects at higher doses $(>0.5 \mu \mathrm{g} / \mathrm{mL}) \mathrm{and}$ induction of cellular differentiation at lower doses $(<0.5 \mu \mathrm{g} / \mathrm{mL})$ and proposed future advances in treatment of neoplastic bleedings.
\end{abstract}

Keywords: Ankaferd,Hemostasis, Neoplastic bleeding,Tumor cell lines

ÖZET

Ankaferd Hemostat (ABS)'nin Lenfoid Neoplastik Hücreler (B-CLL ve RAJI Tümör Hücre dizileri) Üzerine Akut in vitro Etkileri ABS (Ankaferd Hemostat) yeni bir bitki kaynaklı hemostatik ajan olarak ortaya çıkmıştır. ABS'in, özellikle tümör ilişkili transkripsiyon faktörleri olmak üzere hücre yüzeyi reseptörleri ve/veya kan proteinleri ile doku proteinleri gibi birçok protein ile etkileşebilmesi biolojik sistemlerde yeni fonksiyonlarını ortaya çıkarmıştır. Bu nedenle, bu çalışmamızda ABS'in lenfoid neoplastik hücreler üzerindeki etkilerini araştırmayı amaçladık. Ankaferd ile (0.5, 1 ve $2 \mu \mathrm{g} / \mathrm{mL}$ dozlarında) muamele edilen B-KLL hücrelerinin şişmesinin durduğu ve 0.1 ile $0.25 \mu \mathrm{g} / \mathrm{mL}$ dozlarına kıyasla \%50'den fazla tümör hücresinin öldüğünü gösterdik. Ek olarak, kültür ortamına Ankaferd eklenmesi ile B-KLL hücrelerinin blastik agresif lenfoid forma dönüşümü engellendi. Bu sonuçlar, yüksek dozlarda $(>0.5 \mu \mathrm{g} / \mathrm{mL})$ antineoplastik etkileri, düşük dozlarda $(<0.5 \mu \mathrm{g} / \mathrm{mL})$ ise hücresel farklılaşmanın uyarılı̆̆ının ipuçlarını vererek neoplastik kanamaların tedavisinde öncül gelişmeler sundu.

Anahtar Kelimeler: Ankaferd, Hemostaz, Neoplastik kanama,Tümör hücre serileri 


\section{INTRODUCTION}

ABS (Ankaferd hemostat), a novel hemostatic agent of plant origin, provides vital erythroid aggregation ${ }^{1}$ covering the entire physiological hemostatic process via a unique protein network depending primarily on the interactions between ABS and blood proteins, particularly with fibrinogen gamma and prothrombin. ${ }^{2}$ Controlled clinical trials indicated the safety and efficacy of topical ABS in distinct clinical backgrounds. ${ }^{3,4}$ Vital erythroid aggregation takes place with the spectrin and ankyrin receptors on the surface of red blood cells (RBC). 5 Those RBC proteins and the required ATP bioenergy are included in the ABS protein library. ${ }^{6}$ ABS also modulates the cellular apoptotic responses to hemorrhagic stress, as well as hemostatic hemodynamic activity ${ }^{7,8}$, and has considerable influence on the proteins present in tissue and blood. Furthermore, dose-dependent reversible down-regulation of proteinase-activated receptor 1 (PAR-1) is mediated by ABS in the presence of lipopolysaccharides (LPS). ${ }^{9}$ Thus, in addition to its anti-hemorrhagic properties, ABS has shown to act as a topical biological response modifier, including the activation of p53 transcription factor. ${ }^{1,6}$

The aim of this study is to assess acute effects of ABS on the lymphoid neoplastic cell lines namely RAJI (Human Burkitt's lymphoma cell line) and BCLL (B-chronic lymphoid leukemia) cells. Since there is preliminary evidence that ABS could have a potential for the alteration of the behaviour of neoplastic cells ${ }^{10,11}$, the overall effects of this unique hemostatic agent on the tumoral microenvironment shall be elucidated for the safety of the topical ankaferd administration in neoplastic bleedings. ${ }^{11}$

\section{MATERIAL AND METHODS \\ Cell Cultures}

To investigate the effect of ABS on lymphoid and hematopoietic neoplastic cells, we co-cultured BCLL cells, RAJI tumor cell lines, HDLM, and K562 with increasing doses of $0.1 \mu \mathrm{g}, 0.25 \mu \mathrm{g}, 0.5 \mu \mathrm{g}$, $1 \mu \mathrm{g}$ and $2 \mu \mathrm{g}$ Ankaferd in $\mathrm{mL}$ for three days up to 14 days. The cells were co-cultured in complete medium [50\% RPMI 1640 (GIBCO-BRL, Gaithersburg, MD), 50\% Click's [Irvine Scientific, Santa Ana, CA] supplemented with $10 \%$ fetal bovine serum (FBS, HyClone, Logan, Utah), $1 \%$ penicillin-streptomycin (Sigma) and 1\% Glutamine (BioWhittaker)]. Inverted microscopic examinations were done in every day from day zero to day 14th. The pictures of co-cultured tumor cells were taken at day zero and day 3rd by Olympus BX51 CCD camera attached computerized microscopy (Japan) at 20x zoom.

\section{Immunophenotyping}

Cells were stained with PE-, FITC-, PerCP-, or APC-conjugated mAbs. We used CD19, CD20, CD30 and CD33 from Becton-Dickinson (Mountain View, CA, USA) and FoxP3 from eBioscience (San Diego, CA, USA). Samples were analyzed using a FACScalibur (BD Pharmingen) and data were analyzed by Cellquest pro software (BD Bioscience, San Jose, CA). Basicly, appropriate volume of PE-, FITC-, and PercP, conjugated Igs $(25 \mu \mathrm{g} /$ $\mathrm{mL}, 25 \mu \mathrm{g} / \mathrm{mL}$ and $6.3 \mu \mathrm{g} / \mathrm{mL}$, particularly) and 10 $\mu \mathrm{L}$ APC- conjugated Igs were added to cells suspended in PBS and incubated for 30 minutes in the dark at room temperature $\left(20^{\circ}\right.$ to $\left.25^{\circ} \mathrm{C}\right)$. Additional 10 minutes of incubation was done after $2 \mathrm{~mL}$ of $1 \mathrm{X}$ FACS Lysing solution was added. The cells were centrifuged at $500 \mathrm{x} \mathrm{g}$ for 5 minutes and the supernatant was removed. Then $3 \mathrm{~mL}$ of wash buffer was added and recentrifuged at $500 \mathrm{x}$ g for 5 minutes. Consequently, the supernatant was removed and $1 \%$ paraformaldehyde solution was mixed thoroughly for fixation and samples were stored at $2^{\circ}$ to $8^{\circ} \mathrm{C}$ until analysis.

\section{Cytometric Bead Array}

To measure the release of the cytokines in the coculture experiments, we collected supernatants after 24 hours of co-culture. We used the BD Human Th1/Th2 Cytokine cytometric bead array (CBA) kit (Becton Dickinson) for detection of human cytokines IFN- $\gamma$, TNF- $\alpha$, IL-10, IL-5, IL-4 and IL-2 in $\mathrm{pg} / \mathrm{mL}$. Analyses were done, with the Becton Dickinson CBA software 32 on the BD FACSCaliber, following the manufacturer's instructions. Basically, the standards with $2.0 \mathrm{~mL}$ of Assay Diluent was reconstituted and serially diluted the standards in the order of 1:2, 1:4, 1:8, 1:16, 1:32, 1:64, 1:128, and 1:256 (300 $\mu \mathrm{L}$ in each). After standards were prepared, capture beads were mixed first to prepare assay. $10 \mu \mathrm{L}$ of each capture beads were mixed together for each samples. $50 \mu \mathrm{L}$ of mixed capture beads were added to all assay tubes including standard dilutions $(50 \mu \mathrm{L})$ and $50 \mu \mathrm{L}$ of ABS containing sample assay tubes. The assay tubes were incubated for 3 hours at room temperature at dark after 50 $\mu \mathrm{L}$ of the Human Th1/Th2 PE Detection Reagent was added to all assay tubes. Following the incuba- 




Figure 1. Acute affects of ABS on lymphoid tumor cell lines. RAJl cells (left) and B-CLL cells (right).

tion $1 \mathrm{~mL}$ of Wash Buffer was added to each assay tube and centrifuged at $200 \mathrm{~g}$ for 5 minutes. The supernatant was aspirated carefully and bead pellet was resuspended in $300 \mu \mathrm{L}$ of Wash Buffer for the flow cytometer analyses. Human Th1/Th2 cytokine standards were run in parallel to prepare the standard curves.

\section{RESULTS}

The first observed affect of the Ankaferd on the hematopoietic tumor cells was the inflation of the cells (Figure 1) (none, x200). The inflation and proliferation continued on B-CLL cells at Day 3 and produced aggregation islands (clusters). The formation of aggregation for the hematopoietic cells was essential for lymphocytes to proliferate and become active on the culture medium (Figure 1) as it mimics lymphoid follicules in vivo. However, Ankaferd treated B-CLL cells did not continue to inflate especially at higher doses and over $0.5 \mu \mathrm{g}$ (at doses $0.5 \mu \mathrm{g}, 1 \mu \mathrm{g}$ and $2 \mu \mathrm{g}$ ) we have observed more than $50 \%$ death of the tumor cells compared to $0.1 \mu \mathrm{g}$ and $0.25 \mu \mathrm{g}$ doses (Figure 1). Flow cytometric analyses confirmed the over 50\% death of the tumor cells (Data not shown) as on microscobic images shown on Figure 1. On the other hand, while B-CLL neoplastic cells are transformed to the blastic aggressive lymphoid forms, the addition of
ABS to the culture medium resulted in freezing as dormant cells. The protein agglutination has started to be observed on the bottom of the well starting at the $0.25 \mu \mathrm{g}$ doses which prevented tumor cell movement and vibration. Ankaferd induced hemostatic protein network was clearly observed at 0.5 $\mu \mathrm{g}, 1 \mu \mathrm{g}$ and $2 \mu \mathrm{g}$ doses (Figure 1). In parallel to the observed ABS-induced hemostatic protein network, the anti-neoplastic effect has been observed over $\% 50$ percent at $0.5 \mu \mathrm{g}$ doses compared to $0.1 \mu \mathrm{g}$ and $0.25 \mu \mathrm{g}$ doses. On the other hand, interestingly the Cytometric Bead Array revealed increments in human IL-4 (Figure 2) in ABS.

\section{DISCUSSION}

ABS has anti-infective $e^{12}$, anti-neoplastic ${ }^{13,14}$, and healing modulator ${ }^{15-20}$ properties based on the current published literature data. The pleiotropic effects of ABS were ascribed to the ABS-induced alterations in the pathobiological events of apopto$\operatorname{sis}^{7-9}$, angiogenesis ${ }^{13,21,22}$, cellular proliferation ${ }^{23,24}$, and cellular dynamics. ${ }^{13,21}$ In the previous investigations, histopathological examination of the damaged vascular structures revealed ABS-induced red blood cell aggregates ${ }^{1,6,25}$ supporting the hypothesis that ABS-induced formation of the protein network with vital erythroid aggregation covers the entire physiological hemostatic process. ${ }^{1}$ Apart from the 


\section{Cytometric Bead Array}

Ankaferd (50 $\mu \mathrm{L})$

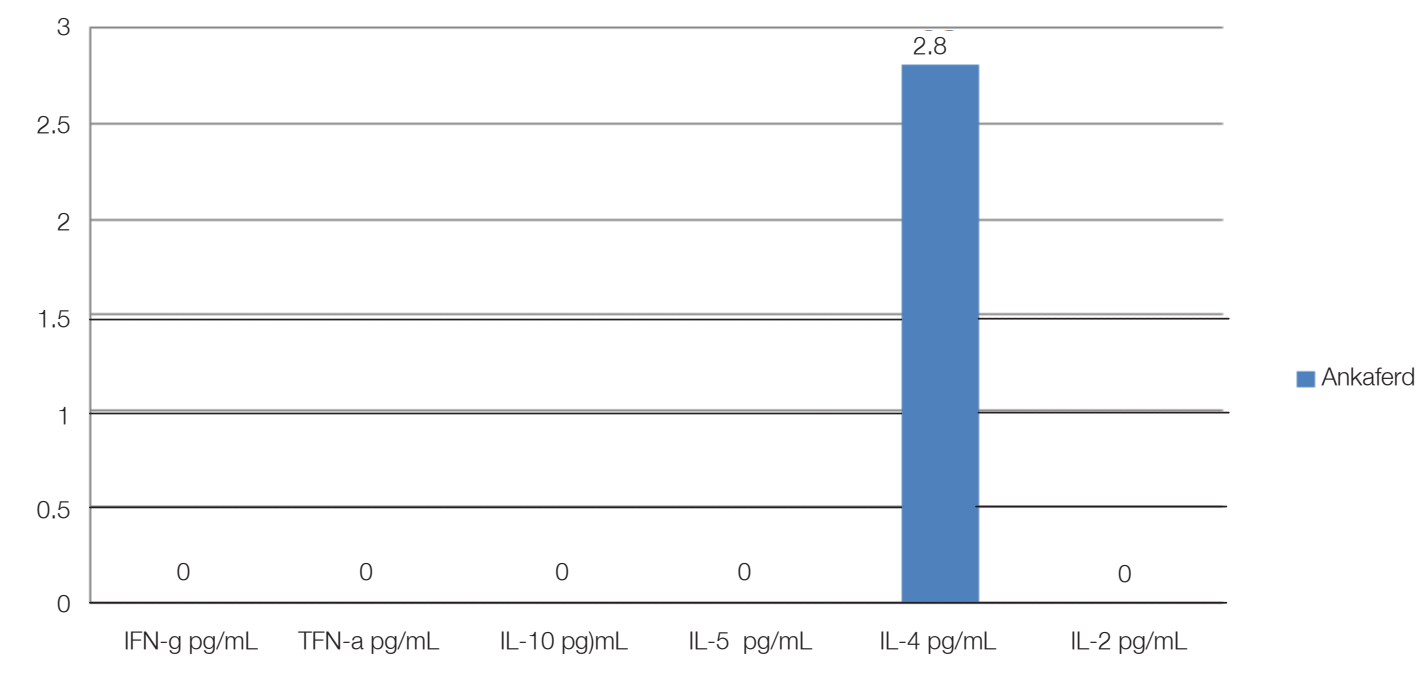

Figure 2. Cytometric bead array results have shown human IL-4 in $50 \mu \mathrm{L}$ of $A B S$ solution.

mechanical hemostasis achieved by ABS, Turhan et al. ${ }^{26}$ previously suggested that ABS diminishes tumor vascularization in gastrointestinal carcinoma bleedings. In this mentioned report, topical ABS application was performed in two patients with tumoral GI bleedings due to rectal and gastric neoplasm. Topical ABS administration to tumoral lesion controlled the bleeding entirely. ABS also decreased tumor microvessel density (MVD) measurements significantly in both of the GI neoplastic tissues compared to the MVDs from the biopsy specimens and the unexposed native neoplastic tissues of the stomach and rectum prior to ABS administration. Based on these results, the authors proposed the existence of secondary and more sustained mechanisms of hemostasis triggered by ABS beyond the initial protein network. ${ }^{26}$

In this study, cytometric bead array revealed increments in IL-4 (Figure 2). This finding is compatible with the previous finding that both IL-4 and its receptor are present within the content of ABS. ${ }^{5}$ In the latter study, the authors has been attributed the anti-cancer activity of ABS to its ability to upregulate critical transcription factors including p53. However, we suppose that ABS has caused apoptosis in lymphoid neoplastic cells since there was a high content of human IL-4 in ABS solution. There is strong data in the literature that IL-4 is related to the biology of CLL. ${ }^{27-31}$ Though, Kay et al. has supposed IL-4 to increase CLL cell resistance to apoptosis ${ }^{27}$ and involved in the mechanism of survival of the leukemic B-cells ${ }^{28}$ in an autocrine way ${ }^{29}$, IL-4 has found to inhibit DNA synthesis in B-cells and suppresses the autocrine proliferation of B-cells even through the suppression of other cytokines..$^{30,31}$ Furthermore, recombinant IL-4 has been tested in Phase II trial for lymphomas and CLL. ${ }^{32}$

In addition to this, there are several crucial components to the ABS-induced protein network. First, in the presence of $\mathrm{ABS}$, vital erythroid aggregation takes place in conjunction with the spectrin and ankyrin receptors on red blood cell membranes. Essential erythroid proteins (spectrin alpha, actindepolymerization factor, NADH dehydrogenase [ubiquinone] 1 alpha subcomplex, mitochondrial NADP [+] dependent malic enzyme). ${ }^{5}$ ABS also up-regulates the GATA/FOG transcription system affecting erythroid functions and urotensin II. ${ }^{6}$ Urotensin II is also an essential component of ABS and acts as a link between injured vascular endothelium, adhesive proteins, and active erythroid cells. Additionally, ABS affects the levels of various critical proteins and factors including protein 2 (AP2), androgen receptor (AR), cyclic AMP 
response element or activating transcription factor 1 (CRE-ATF1), cyclic AMP response element binding protein (CREB), E2F1-5, E2F6, interferon (IFN)-stimulated response element (ISRE), MycMax, nuclear factor-1 (NF-1), protein 53 or tumor protein 53 (p53), peroxisome proliferator-activated receptor (PPAR), and Yin Yang 1 (YY1) transcription factors. ${ }^{6,9}$ These regulator molecules affect distinct steps of cellular proliferation such as cell vascular hemostasis, angiogenesis, signal transduction, apoptosis, inflammation, acute phase reaction, immunity, and several metabolic molecular pathways. ${ }^{13,21,22}$ Therefore, the protein content and their effects on the transcriptomics may be active in the cellular action of Ankaferd hemostat.

The effectiveness of ABS for the control of topical bleedings in cancer patients have been reported by $\mathrm{Al}$ et al. ${ }^{33}$ Sixty-nine cancer patients that were admitted for port insertion to a university hospital was randomized either to take a wet compress form of ABS or regular dry sterile sponges to stop the bleeding that occurs during the clinically indicated vascular port insertion. The average time needed to stop the bleeding was $32.97 \pm 29.9 \mathrm{~s}$ for ABS group and $123.75 \pm 47.5 \mathrm{~s}$ for dry sponge group. ABS was proven to stop local bleeding in a shorter time, with a lower recurrence rate in comparison with the sterile sponge. ${ }^{33}$ Therefore, the overall effects of this unique hemostatic agent on the tumoral microenvironment shall be elucidated for the safety of the topical Ankaferd administration in neoplastic bleedings.

Previous investigations disclosed the antineoplastic effects of ABS on the Saos-2 osteosarcoma cell survival and growth (reviewed in1). Saos-2, an osteosarcoma cell line often employed in drug resistance studies, were cultured in RPMI media containing $10 \%$ FCS, $1 \%$ pen/strep, and $1 \%$ Na-pyruvate. Following the cultivation, cells were transferred into 12-well tissue plates, in which $2,4,6,8,10$ $\mu 1 / \mathrm{ml}$ concentrations of ABS solution was added to the growth medium. Control group was cultured in growth media without ABS. Growth of Saos- 2 cells was monitored for 17 days during which yellow and opaque-looking aggregates were reported in cultures growing with the presence of ABS. There was a dose-dependent inhibition in cell proliferation and a marked decrease was observed in the survival of Saos-2 cells. Aggregate formation increased with higher doses of ABS and dose-dependent inhibition was observed in cell invasion. ABS treated Saos-2 osteosarcoma cells were determined to lose adhesion in vitro. In another study, successful antineoplastic effects of ABS on colon cancer (as represented by the reproduction of $\mathrm{CaCo}-2$ cells) were demonstrated. Two types of cells were placed separately in 12-well tissue culture containers and ABS solutions with $2,4,6,8$ and $10 \mu \mathrm{L} / \mathrm{mL}$ concentrations were added to the culture medium. The cells cultivated in culture medium without exposure to ABS were used as control. The growth of CaCo-2 and Saos-2 cells was monitored for 16 days. ABS application to culture medium resulted in yellow and cloudy aggregates, increasing in parallel with ABS concentration. Therefore, it was concluded that the inhibition of cellular reproduction and decrease in viability of human colon CaCo-2 cells were correlated with applied ABS concentration in vitro. The results have shown that the invasion of cells was also inhibited in a dose-dependent manner. The inhibitor effect of ABS on CaCo- 2 cells was observed at $2 \mu \mathrm{L} / \mathrm{mL}$ level and become more prominent at $10 \mu \mathrm{L} / \mathrm{ml}$ concentration. It was also noted that $\mathrm{CaCo}-2$ cells that were exposed to ABS, lost their adhesive characteristics in vitro and significant viability loss was observed (reviewed in1). In a study by Odabas et al. ${ }^{34}$, the cytotoxicity of ABS was evaluated on human pulp fibroblasts in vitro. ABS was eluted with fresh Dulbecco's Modified Eagle's Medium (DMEM) without serum for $72 \mathrm{~h}$, at $37^{\circ} \mathrm{C}$. The results of this study have shown that ABS is cytotoxic to human pulp fibroblasts by modified 3-(4,5-dimethyl-thiazol2-yl)-2,5-diphenyl-tetrazolium bromide assay, depended on the concentration of ABS applied. More dilutions exhibited less cytotoxic characteristics compared to the more concentrated forms on human pulp fibroblasts. Considering the fact that an ideal hemostatic agent should be free of cytotoxicity, it has been recommended to remove unused ABS by cleaning to minimize the postoperative complications once the hemostasis is achieved. ${ }^{34}$ Those observations are in accordance with our findings in this study that the anti-neoplastic effect has been observed over $50 \%$ at $0.5 \mu \mathrm{g}$ doses compared to 0.1 $\mu \mathrm{g}$ and $0.25 \mu \mathrm{g}$ doses in lymphoid neoplastic cells whereas low ABS doses induced cellular differentiation. On the other hand, while B-CLL neoplastic cells are transformed to the blastic aggressive lymphoid forms, the addition of ABS to the culture resulted in freezing as dormant cells. Regarding the effects of ABS on tumor angiogenesis in $\mathrm{vivo}^{26}$, in the next step based on our experiments, the biological background under the anti-proliferative effects of ABS on the lymphoid cells should be searched in 
the in vivo transgenic animal models representing neoplastic disorders.

Studies documented in literature shows that ABS represents an alternative treatment modality for many different types of external bleedings that are resistant to conventional methods. The ability of ABS to induce formation of a protein network not only makes it an effective hemostatic agent, but also confers anti-infective, anti-neoplastic, and healing modulator properties to the extract. Future controlled studies are needed to shed further light on the expanding spectrum of ABS effects in hemostasis and related areas.

\section{REFERENCES}

1. Haznedaroglu BZ, Beyazit Y, Walker SL, Haznedaroglu IC. Pleiotropic cellular, hemostatic, and biological actions of Ankaferd hemostat. Crit Rev Oncol Hematol 83: 21-34, 2012.

2. Ozel-Demiralp D, Igci N, Ayhan B, et al. Prohemostatic and antithrombin activities of Ankaferd hemostat are linked to fibrinogen gamma chain and prothrombin by functional proteomic analyses. Clin Appl Thromb Hemost 18: 604-610, 2012.

3. Teker AM, Korkut AY, Gedikli O, Kahya V. Prospective, controlled clinical trial of Ankaferd Blood Stopper in children undergoing tonsillectomy. Int J Pediatr Otorhinolaryngol 73: 1742-1745, 2009.

4. Teker AM, Korkut AY, Kahya V, Gedikli O. Prospective, randomized, controlled clinical trial of Ankaferd Blood Stopper in patients with acute anterior epistaxis. Eur Arch OtorhinoLaryngol 267: 1377-1381, 2010.

5. Demiralp DO, Haznedaroglu IC, Akar N. Functional proteomic analysis of Ankaferd Blood Stopper. Turkish J Hematol 27: 70-77, 2010.

6. Yilmaz E, Gulec S, Torun D, et al. The effects of Ankaferd Blood Stopper on transcription factors in HUVEC and the erythrocyte protein profile. Turkish J Hematol 28: 276-285, 2011.

7. Huri E, Akgul T, Astarci M, Ustun H, Germiyanoglu C. The Effect of a Novel Hemostatic Agent, Ankaferd Bloodstopper (Abs), on Renal Tubular Apoptosis in Rat Partial Nephrectomy Model. J Endourol 23: A2, 2009.

8. Huri E, Haznedaroglu IC, Akgul T, et al. Biphasic effects of ankaferd blood stopper on renal tubular apoptosis in the rat partial nephrectomy model representing distinct levels of hemorrhage. Saudi Med J 30: 864-868, 2010

9. Karabiyik A, Gulec S, Yilmaz E, et al. Reversible proteaseactivated receptor 1 downregulation mediated by Ankaferd blood stopper inducible with lipopolysaccharides inside the human umbilical vein endothelial cells. Clin Appl Thromb Hemost 17: E165-170, 2011.

10. Arslan S, Haznedaroglu IC, Öz B, Goker H. Endobronchial application of Ankaferd blood stopper to control profuse lung bleeding leading to hypoxemia and hemodynamic instability. Resp Med 2: 144-146, 2009.

11. Kurt M, Akdogan M, Onal IK, et al. Endoscopic topical application of Ankaferd Blood Stopper for neoplastic gastrointestinal bleeding: A retrospective analysis. Dig Liver Dis 42: 196-199, 2010.

12. Akkoc N, Akcelik M, Haznedaroglu IC, et al. In Vitro Anti-Bacterial Activities of Ankaferd Medicinal Plant Extract. Turkiye Klinikleri Tip Bilimleri Dergisi 29: 410-415, 2009

13. Beyazit $\mathrm{Y}$, Kurt M, Kekilli M, et al. Evaluation of hemostatic effects of Ankaferd as an alternative medicine. Altern Med Rev 15: 329-36, 2010.

14. Turhan N, Bilgili $\mathrm{H}$, Captug $\mathrm{O}$, et al. Evaluation of a haemostatic agent in rabbits. Afr J Tradit Complement Altern Med 8: 61-65, 2011.

15. Akalin C, Kuru S, Barlas AM, et al. Beneficial effects of Ankaferd Blood Stopper on dermal wound healing: an experimental study. Int Wound J 11: 64-68, 2014.

16. Akbal E, Koklu S, Karaca G, et al. Beneficial effects of Ankaferd Blood Stopper on caustic esophageal injuries: an experimental model. Dis Esophagus 25: 188-194, 2012.

17. Akgul T, Huri E, Ayyildiz A, et al. Haemostatic and Histopathological Effects of Ankaferd Blood Stopper, on Penile Cavernosal Tissue in Rats. UHOD19: 159-165, 2009.

18. Gunay M, Amanvermez R. The effect of ankaferd on bone fracture healing. Clin Chem Lab Med 49: S828, 2011.

19. Isler SC, Demircan S, Cakarer S, et al. Effects of folk medicinal plant extract Ankaferd Blood Stopper on early bone healing. J Appl Oral Sci 18: 409-414, 2010.

20. Karaman K, Bostanci EB, Celep B, et al. In Vivo Healing Effects of Ankaferd Blood Stopper on the Residual Pancreatic Tissue in a Swine Model of Distal Pancreatectomy. Indian J Surg DOI 10.1007/s12262-013-0828-1, 2014 (in press).

21. Aktas A, Er N, Onur MA. Effects of Ankaferd Blood Stopper (R) on Vascular Response in Rat Carotid Artery. UHOD 20: 156-162, 2010.

22. Beyazit $Y$, Kekilli M, Haznedaroglu IC, et al. Ankaferd hemostat in the management of gastrointestinal hemorrhages. World J Gastroenterol 17: 3962-3970, 2011.

23. Mihmanli A, Ulker Z, Alpsoy L, Ezirganli S. Evaluation of cytotoxicity of a new hemostatic agent Ankaferd Blood Stopper using different assays. Hum Exp Toxicol 31: 780-787, 2012.

24. Tas A, Koklu S, Beyazit $Y$, et al. Percutaneous ankaferd injection to in vivo liver tissue in comparison to ethanol in an experimental rat model. Clin Res Hepatol Gastroenterol 35: 549-553, 2011.

25. Ulus AT, Turan NN, Ozyalcin S, et al. Surgical and histopathological effects of topical Ankaferd hemostat on major arterial vessel injury related to elevated intra-arterial blood pressure. Turkish J Hematol 28: 206-212, 2011.

26. Turhan N, Kurt M, Shorbagi A, et al. Topical Ankaferd Blood Stopper Administration to Bleeding Gastrointestinal Carcinomas Decreases Tumor Vascularization. Am J Gastroenterol 104: 2874-2877, 2009. 
27. Kay NE, Han L, Bone N, Williams G. Interleukin 4 content in chronic lymphocytic leukaemia (CLL) B cells and blood CD8+ T cells from B-CLL patients: impact on clonal B-cell apoptosis. Br J Haematol 112: 760-7, 2001.

28. Mainou-Fowler T, Proctor SJ, Miller S, Dickinson AM. Expression and production of interleukin 4 in B-cell chronic lymphocytic leukaemia. Leuk Lymphoma 42: 689-98, 2001.

29. Kay NE, Pittner BT. IL-4 biology: impact on normal and leukemic CLL B cells. Leuk Lymphoma 44: 897-903, 2003.

30. Luo H, Rubio M, Biron G, et al. Antiproliferative effects of IL-4 in B chronic lymphocytic leukemia. J Immunother 10: 418-425, 1991.

31. Lee D, Swisher SG, Minehart EH, et al. Interleukin-4 downregulates interleukin-6 production in human peripheral blood mononuclear cells. J Leukocyte Biol 47: 475-479, 1990.

32. Wiernik PH, Dutcher JP, Yao X, et al. Phase II study of interleukin-4 in indolent B-cell non-Hodgkin lymphoma and B-cell chronic lymphocytic leukemia: a study of the Eastern Cooperative Oncology Group (E5Y92). J Immunother 33: 10061009, 2010.

33. Al B, Yildirim C, Cavdar M, Zengin S, et al. Effectiveness of Ankaferd blood stopper in the topical control of active bleeding due to cutaneous-subcutaneous incisions. Saudi Med J 30: 1520-1525, 2009.

34. Odabas ME, Erturk M, Cinar C, et al. Cytotoxicity of a new hemostatic agent on human pulp fibroblasts in vitro. Med Oral Patol Oral Cir Bucal 16: e584-587, 2011.

\section{Correspondence}

Dr. İbrahim C. HAZNEDAROĞLU

Hacettepe Üniversitesi Tıp Fakültesi

Hematoloji Bölümü

06100, Sihhiye, ANKARA / TURKEY

Tel: (+90.312) 3052543

e-mail: haznedar@yahoo.com 